\title{
EFEKTIFITAS METODE PEMBELAJARAN ASSISTED LEARNING MODEL SCAFFOLDING PADA MATA KULIAH BAHASA ARAB
}

\author{
Neli Rahmaniah \\ UIN Syarif Hidayatullah Jakarta, Indonesia \\ E-mail: neli.rahmaniah@uinjkt.ac.id
}

\begin{abstract}
One of the problems in learning Arabic until now is that there is no hope that all students from Islamic Universities who use Arabic are studied in any faculty that can make a grouping of knowledge and religion. That is because the competency standards that have occurred so far lack focus on Arabic material for special purposes, so students must pass Arabic courses, but still find it difficult to use Arabic as a means of conducting Islamic studies and communication according to their respective majors. This paper tries to describe the curriculum design and learning models in Arabic subjects and improve the learning methods of scaffolding models for the help of effectiveness in the Medical Education Study Program at the Faculty of Medicine, UIN Jakarta. This research method uses a qualitative descriptive method with case studies on learning Arabic in the Medical Study Program of FIK UIN Jakarta. Data collection techniques carried out by participatory observation, interviews, questionnaires and documentation. While the data analysis technique is done by data reduction, data display and conclusion drawing. This research was conducted by (1) analyzing the needs of early stage students, (2) setting learning objectives and selecting learning materials based on needs analysis by lecturers and MEU by making modules (3) applying scaffolding learning models in the framework of learning Arabic. The results showed; (1) The needs of PSPD FIK UIN Jakarta students in learning Arabic, in addition to general objectives that can be understood by the Qur'an and Hadith which are the main sources of teaching and Islamic law, also for more specific purposes to be able to communicate in Arabic while going Hajj also when invited as a medical team of Hajj officers. In addition, the Arabic learning objectives supported by other competency modules studied at PSPD, which are supported by the Muslim Doctors module, (2) The activity of the Arabic language module using scaffolding learning models has been running 90\% according to the plan. In the Arabic module the pretest value of the posttest is $56.22 \%$. According to students, Arabic learning materials can contribute in increasing the professionalism of doctors.
\end{abstract}

Keywords: Assisted Learning; Arabic Learning; Needs Analysis; Scaffolding

Abstrak. Salah satu problem dalam pembelajaran bahasa Arab hingga saat ini yaitu belum tercapainya harapan agar semua mahasiswa khususnya dari Universitas Islam bahwa dengan bekal bahasa Arab yang dipelajari di fakultas apapun dapat melakukan integrasi ilmu dan agama. Hal itu disebabkan karena standar kompetensi yang diajarkan selama ini kurang fokus pada materi bahasa Arab untuk tujuan khusus, sehingga meskipun mahasiswa telah lulus mata kuliah bahasa Arab, tetapi masih mengalami kesulitan menggunakan bahasa Arab itu sebagai alat melakukan kajian keislaman maupun komunikasi sesuai jurusan masingmasing. Tulisan ini bertujuan untuk mendeskripsikan desain kurikulum dan model pembelajaran pada mata kuliah bahasa Arab dan sejauhmana efektifitas metode assisted learning model scaffolding pada program studi Pendidikan Dokter Fakultas Ilmu Kedokteran UIN Jakarta.Metode penelitian ini menggunakan kualitatif deskriptif dengan jenis studi kasus pada pembelajaran bahasa Arab Program Studi Pendidikan Dokter FIK UIN Jakarta. Teknik pengumpulan data dilakukan dengan observasi partisipatif, wawancara, kuesioner dan dokumentasi. Sedangkan teknik analisa data dilakukan dengan data reduction, data display dan conclusion drawing. Riset ini dilakukan dengan (1) analisis kebutuhan mahasiswa tingkat awal, (2) penetapan tujuan pembelajaran dan pemilihan materi pembelajaran berdasarkan analisis kebutuhan oleh dosen dan MEU dengan membuat modul (3) penerapan model pembelajaran scaffolding dalam rangka efektivitas pembelajaran bahasa Arab. Hasil penelitian menunjukkan ; (1) Kebutuhan mahasiswa PSPD FIK UIN Jakarta dalam pembelajaran bahasa Arab, selain untuk tujuan umum yakni dapat memahami AlQur'an dan Hadist yang keduanya merupakan sumber pokok ajaran dan hukum Islam, juga untuk tujuan yang lebih khusus lagi yakni agar dapat berkomunikasi dalam bahasa Arab saat pergi haji maupun saat bertugas sebagai tim medis petugas haji. Selain itu, tujuan pembelajaran bahasa Arab bertujuan sebagai pendukung kompetensi modul lain yang dipelajari di PSPD, yakni supaya terintegrasi dengan modul Dokter Muslim, (2) Kegiatan modul bahasa Arab dengan menggunakan model pembelajaran scaffolding telah berjalan $90 \%$ sesuai dengan rencana. Pada modul bahasa Arab didapatkan peningkatan nilai pretest terhadap posttest sebesar 56.22\%. Menurut mahasiswa, materi pembelajaran bahasa Arab dapat berkonstribusi dalam peningkatan profesionalisme dokter.

Kata Kunci: Assisted Learning; Pembelajaran bahasa Arab; Analisis Kebutuhan; Scaffolding

Permalink/DOI: https://doi.org/10.15408/mimbar.v36i1.13032 


\section{Pendahuluan}

Pembelajaran adalah proses interaksi antara peserta didik dengan pendidik dan sumber belajar pada suatu lingkungan belajar. Agar proses interaksi ini dapat berjalan secara optimal dalam pencapaian tujuan pembelajaran, maka kegiatan pembelajaran harus dikelola dengan baik. Pengelolaan pembelajaran dimaksudkan sebagai suatu seni dalam mengoptimalkan segala sumber-sumber daya kelas demi terciptanya proses pembelajaran yang efektif dan efisien. Pengelolaan pembelajaran juga diartikan sebagai upaya pendidik untuk menciptakan dan mengendalikan kondisi belajar serta memperbaikinya apabila terjadi gangguan maupun penyimpangan, sehingga proses pembelajaran dapat berlangsung sesuai harapan. Proses pembelajaran pada satuan pendidikan diselenggarakan secara interaktif, inspiratif, menyenangkan, menantang, memotivasi peserta didik untuk berpartisipasi aktif, serta memberikan ruang yang cukup bagi prakarsa, kreativitas, dan kemandirian sesuai dengan bakat, minat, dan perkembangan fisik serta psikologis peserta didik. Pendidikan diselenggarakan dengan memberikan keteladanan, membangun kemauan, dan mengembangkan kreativitas peserta didik dalam proses pembelajaran (UU No.20/2003).

Berdasarkan hal tersebuat diatas, maka diperlukan upaya pengembangan kualitas pembelajaran, termasuk pembelajaran bahasa Arab. Kualitas pembelajaran banyak tergantung pada bagaimana pembelajaran itu dirancang. Rancangan pembelajaran biasanya dibuat berdasarkan pendekatan rancangannya sesuai dengan teori yang dikembangkan mengenai belajar, misalnya teori konstruktivisme yang menekankan pembelajaran "student-centered". Bentuk pelaksanaan pembelajaran berdasarkan teori ini dilaksanakan melalui belajar aktif, belajar mandiri, belajar kooperatif dan kolaboratif, generative learning dan problem-based learning. Tidak dapat dipungkiri, bahwa seseorang yang mempelajari suatu bahasa asing akan mendapati kesulitan-kesulitan, yang mana kesulitan-kesulitan ini dapat diperkecil apabila dia memiliki faktor-faktor pendorong yang sangat kuat atau dengan kata lain dia memiliki keinginan yang kuat untuk mempelajari bahasa tersebut.

Bahasa Arab merupakan salah satu bahasa asing yang lambat laun mulai dipelajari oleh para pembelajar di dunia. Di Indonesia pun bahasa ini banyak dipelajari, terlebih lagi bahwa mayoritas masyarakatnya beragama Islam, yang mana mereka memiliki kitab Al-Qur'an yang diturunkan dengan bahasa Arab. Menurut Prof. Dr. Aziz Fakhrurrozi, MA, salah seorang dosen bahasa Arab dan merupakan Guru besar UIN Syarif Hidayatullah dalam pembahasannya pada seminar Nasional yang bertema "Pembelajaran Bahasa Arab Berorientasi Masa Depan" (Senin, 8 April 2013), beliau menjelaskan bahwa terdapat lima rukun (pilar) negara bisa maju, yaitu : Politik yang stabil, Ekonomi yang stabil, Pendidikan yang bermutu, Hukum yang berwibawa, serta Moralitas yang kokoh. Lalu, menghubungkannya dengan dua tujuan dasar belajar Bahasa Asing (khususnya Bahasa Arab), yaitu: memahami teks, dan berkomunikasi. Hampir kedua tujuan tersebut tidak pernah tercapai dengan baik, mungkin hanya salah satunya. Dan itu pun patut disyukuri, karena setidaknya bisa mengaplikasikan salah satu tujuan belajar bahasa tersebut. Menurut beliau, Ketidak tercapainya tujuan tersebut, sesungguhnya bukan disebabkan karena faktor sulitnya bahasa yang dipelajari, melainkan disebabkan karena faktor non bahasa, yaitu faktor minat yang rendah, kurangnya motivasi, dan bahkan tidak dianggap penting. Maka dari itu, kita harus mencari upaya strategis hal apa saja yang dapat meningkatkan motivasi belajar bahasa Arab secara menyeluruh. 


\section{Analisis Kebutuhan}

Analisa atau analisis dalam kajian linguistik diartikan dengan sebuah kajian yang dilaksanakan terhadap sebuah bahasa guna meneliti struktur bahasa tersebut secara mendalam. Analisis juga diartikan dengan penyelidikan terhadap suatu peristiwa baik berupa karangan atau sebuah perbuatan untuk mengetahui keadaan yang sebenarnya dari segi sebab-musabab maupun duduk perkaranya (KBBI, 2005; 43). Kebutuhan dapat diartikan dengan sesuatu yang dibutuhkan. Sebuah kesenjangan antara apa yang ada dan apa yang seyogyanya ada. Sedangkan kebutuhan bagi seorang pendidik adalah sesuatu yang digunakan untuk menentukan latar belakang atas konsep keanekaragaman yang tidak terbatas, guna menyeleksi bidang-bidang normatif yang mengandung kekurangan untuk disediakan penyesuaiannya oleh pendidik (Taringan, 80 ).

Kebutuhan sebagai sesuatu yang urgen dalam perencanaan kurikulum, berkaitan erat dengan pengembangan kurikulum dan pembelajaran. Kebutuhan dalam konsep ini didefinisikan sebagai actual circumstance (keadaan aktual/keadaan yang sedang diperbincangkan) dan envisional ideal circumtance (keadaan ideal yang dicita-citakan). Atau dengan kata lain, suatu perbedaan antara keadaan riil dan kondisi ideal (Hamalik, 2008; 188). Nation-Macalister (2010) melihat analisis kebutuhan sebagai kegiatan mencari tahu apa yang sudah diketahui pemelajar dan apa yang mereka perlu ketahui. Analisis kebutuhan memastikan bahwa program pengajaran akan berisikan hal-hal yang relevan dan berguna untuk dipelajari.

Analisis kebutuhan adalah proses penjaringan informasi tentang kompetensi yang dibutuhkan anak didik sesuai dengan jenjang pendidikan. Kebutuhan ini dijaring dengan berbagai teknik dari lapangan, misalnya dengan wawancara, observasi, dan mungkin strudi dokumentasi. Analisis kebutuhan merupakan alat yang konstruktif dan positif untuk melakukan perubahan. Perubahan yang didasarkan atas logika yang bersifat rosional, perubahan fungsional yang dapat memenuhi kebutuhan kelompok dan individu. Perubahan ini menunjukkan upaya formal yang sistematis menentukan dan mendekatkan jarak kesenjangan antara "seperti apa yang ada" dengan "bagaimana seharusnya".

Analisis kebutuhan bisa berlangsung sebelum, selama, atau setelah suatu program pembelajaran bahasa. Sebagian besar literatur pada analisis kebutuhan didasarkan pada asumsi bahwa perencanaan yang berlangsung sebagai bagian dari pengembangan suatu pelatihan. Asumsi tersebut menunjukkan bahwa ada waktu dan sumber daya yang tersedia untuk merencanakan, mengumpulkan, dan meneliti relevansi informasi untuk suatu program pembelajaran. Informasi yang dikumpulkan kemudian dianalisis dalam rangka memperoleh suatu pandangan yang menyeluruh bagi kebutuhan siswa sebagai dasar untuk mengevaluasi dan meninjau ulang program tersebut.

Penulis menggunakan kerangka Nation dan Macalister (2010) yang melihat tiga faktor dalam analisis lingkungan, yaitu pemelajar, pengajar, dan situasi. Kerangka tersebut dipilih karena memungkinkan cara pandang yang lebih komprehensif dan sistematis. Dalam melihat kebutuhan pemelajar digunakan kerangka Hutchinson dan Waters, yakni: 1) Necessities, yakni kemampuan yang dituntut, 2) Lacks, yaitu melihat pada keadaan pemelajar sekarang. 3) Wants atau kebutuhan subyektif pemelajar. Peneliti sependapat dengan Nation-Macalister yang meminjam konsep Hutchinson dan Waters bahwa meski bukan yang paling komprehensif, konsep necessities, lacks, dan wants cukup memadai sebagai alat analisis. Hasil analisis kebutuhan bersama dengan analisis lingkungan membantu perancang kurikulum dalam menyusun kurikulum. 


\section{Metode Assisted Learning Model Scaffolding dalam Pembelajaran Bahasa Arab}

Pembelajaran bahasa Arab di Indonesia sudah menggunakan metode-metode yang berbeda yang tujuannya untuk menyesuaikan perkembangan dan kemajuan zaman, dan mencapai hasil yang maksimal. Menentukan metode yang tepat untuk pembelajaran bukanlah hal yang mudah, karena banyaknya metode-metode dengan kelebihan dan kekurangan yang harus dipertimbangkan. Dengan metode yang sesuai dan tepat, maka diharapkan sasaran dan tujuan pembelajaran bahasa Arab dapat tercapai secara maksimal. Metode adalah rencana menyeluruh yang berkenaan dengan penyajian materi bahasa secara teratur, tidak ada satu bagian yang bertentangan dengan yang lain dan semuanya berdasarkan approach yang telah dipilih. Sifatnya, procedural (Arsyad, 2010).

Metode ialah suatu cara kerja yang sistematik dan umum, terutama dalam mencari kebenaran ilmiah. Dalam kaitannya dengan pembelajaran bahasa arab maka pembahasan metode akan selalu bertolak dari hakikat usaha menyampaikan bahan pelajaran kepada peserta didik agar pelajaran itu diterima. Di dalam tangan siapa metode itu tergenggam, maka kepadanya dituntut suatu keampuan dan keterampilan menggunakannya (Daradjat, dkk, 1996). Menurut Soenjono (2000), pembelajaran bahasa harus terpusat pada pembelajar/peserta didik, yaitu dengan menggunakan SCM. Hal itu karena penggunaan bahasa itu bersifat kreatif, dan kreativitas itu ada di tangan si pengguna yang tidak lain adalah si pembelajar. Dengan berkembangnya pemikiran tentang pembelajaran yang berfokus kepada peserta didik (Student Centred Model), maka pembelajaran bahasa Arab sebagai bahasa asing juga berlaku hal yang sama, yakni menggunakan model SCM. Adapun salah satu model pembelajaran yang sesuai dengan pendekatan konstruktivisme adalah metode scaffolding. Model ini bisa diterapkan dalam pembelajaran bahasa, termasuk bahasa Arab.

Model pembelajaran diartikan sebagai prosedur sistematis dalam mengorganisasikan pengalaman belajar untuk mencapai tujuan belajar. Dapat juga diartikan suatu pendekatan yang digunakan dalam kegiatan pembelajaran. Dengan kata lain, model pembelajaran merupakan suatu rencana atau pola yang digunakan untuk merancang pembelajaran tatap muka di dalam ruang kelas dan untuk menyusun materi pengajaran. Jadi, sebenarnya model pembelajaran memiliki arti yang sama dengan pendekatan, strategi atau metode pembelajaran (Cahyo, 2013). Penggunaan metode pembelajaran model scaffolding bertujuan untuk mendorong siswa menjadi siswa yang mandiri dan mengatur diri sendiri (self regulating). Begitu pengetahuan dan kompetensi belajar siswa meningkat, guru secara berangsur-angsur mengurangi pemberian dukugan. Jika siswa tidak mampu mencapai kemandirian, guru kembali ke sistem dukungan untuk membantu siswa memperoleh kemajuan sampai mereka mampu mencapai kemandirian.

Menurut Vygotsky, perkembangan kognitif terjadi melalui interaksi dan percakapan seorang anak dengan lingkungan di sekitarnya. Orang lain disebut sebagai pembimbing atau guru. Pada umumnya, bimbingan ini dikomunikasikan melalui bahasa. Jerome Bruner menyebut bantuan orang dewasa dalam proses belajar anak dengan istilah scaffolding, yaitu sebuah dukungan untuk belajar dan memecahkan problem. Dukungan dapat berupa isyarat-isyarat, peringatan-peringatan, motivasi, memecahkan problem dalam beberapa tahap, memberikan contoh atau segala sesuatu yang mendorong seorang siswa untuk tumbuh dan menjadi pelajar yang mandiri dalam memecahkan problem yang dihadapinya.

Secara umum, langkah-langkah pembelajaran model scaffolding dapat dilihat sebagai berikut:

1. Menjelaskan materi pembelajaran. 
2. Menentukan zone of proximal development (ZPD) atau level perkembangan siswa berdasarkan tingkat kognitifnya dengan melihat nilai hasil belajar sebelumnya.

3. Mengelompokkan siswa menurut ZPD-nya.

4. Memberikan tugas belajar berupa soal-soal berjenjeng yang berkaitan dengan materi pembelajaran.

5. Mendorong mahasiswa untuk bekerja dan belajar menyelesaikan soal-soal secara mandiri dengan berkelompok.

6. Memberikan bantuan berupa bimbingan, motivasi, pemberian contoh, kata kunci atau hal lain yang dapat memancing mahasiswa ke arah kemandirian belajar.

7. Mengarahkan siswa yang memiliki ZPD yang tinggi untuk membantu siswa yang memiliki ZPD rendah.

Program Studi Pendidikan Kedokteran (PSPD) merupakan salah satu program studi pada fakultas kedokteran UIN Syarif Hidayatullah Jakarta, yang beralamat di jalan Kertamukti Ciputat Tangerang Selatan telah berdiri secara resmi sejak tahun 2005 berdasarkan Surat Keputusan Direktur Jenderal Pendidikan Tinggi Departemen Pendidikan Nasional RI nomor: 1356/D/T2005.

Tujuan dari prodi ini yaitu untuk Menyiapkan peserta didik menjadi anggota masyarakat yang memiliki kemampuan akademik profesional yang dapat menerapkan, mengembangkan dan/atau menciptakan ilmu pengetahuan dan teknologi kedokteran dan ilmu pengetahuan agama Islam secara integratif, serta menerapkan, mengembangkan dan menyebarluaskan ilmu pengetahuan dan teknologi kedokteran dan ilmu agama Islam secara integratif serta mengupayakan pemanfaatannya untuk meningkatkan taraf kehidupan masyarakat dan dalam upaya pembangunan karakter bangsa.

Sesuai dengan tingkatan, jenis sekolah dan program pendidikan yang diberikan kita mengenal empat tingkatan tujuan pendidikan (Sudjana, 2009) yaitu:

a. Tujuan umum pendidikan, yakni pembentukan manusia pancasila.

b. Tujuan isntitusional (tujuan lembaga pendidikan).

c. Tujuan kurikuler (tujuan bidang studi atau mata pelajaran).

d. Tujuan instruksional (tujuan proses belajar dan mengajar)

Tujuan umum pendidikan nasional adalah rumusan kualifikasi umum yang diharapkan telah dimiliki oleh setiap warga Negara Indonesia setelah menyelasaikan suatu program pendidikan. Tujuan umum ini lazimnya dikemukakan di dalam dokumen-dokumen resmi Negara seperti keputusan MPR, Undang-undang atau Keputusan Menteri pendidikan dan kebudayaan. Tujuan institusional adalah rumusan kualifikasi yang diharapkan dimiliki oleh setiap orang yang telah menyelesaikan pendidikan pada tingkat dan jenis lembaga-lembaga pendidikan (sekolah-sekolah) tertentu. Untuk melaksanakan tugas pendidikan seperti yang digariskan oleh tujuan umum pendidikan diatas, adalah dibebankan kepada lembaga-lembaga pendidikan. Setiap lembaga tersebut memiliki tugas yang harus diselesaikan dalam bentuk rumusan tujuan pendidikan institusional yang harus dicapai pada akhir program pendidikannya. Tujuan kurikuler adalah rumusan-rumusan kualifikasi yang khusus yang harus dimiliki oleh setiap murid atau pelajar atau mahasiswa, setelah mereka mengikuti program kegiatan kurikuler. Misalnya kita mengenal bidang-bidang kurikulum seperti matematika, ilmu sosial, IPA, bahasa, 
pendidikan agama, dan sebagainya, maka masing-masing bidang kurikulum atau bidang studi tersebut mengemban tugas-tugas yang dirumuskna dalam tujuan kurikuler.

Tujuan intruksional adalah rumusan tingkah laku yang diharapkan dimiliki oleh murid atau pelajar atau mahasiswa, setelah mengikuti pengajaran tertentu, pada suatu saat, atau pada jangka waktu tertentu, maka dengan tujuan instruksional inilah kita benar-benar dapat menyusun suatu program pengajaran yang riil atau nyata, karena tujuan-tujuan kurikuler penyelesaiannya dibebankan pada sauatu bidang kurikulum hanyalah bisa dilaksanakan pada kegiatan intruksional dalam bidang kurikulum tersebut.

Nana Syaodih Sukmadinata (2002) mengidentifikasi 4 (empat) manfaat dari tujuan pembelajaran, yaitu: (1) memudahkan dalam mengkomunikasikan maksud kegiatan belajar mengajar kepada siswa, sehingga siswa dapat melakukan perbuatan belajarnya secara lebih mandiri; (2) memudahkan guru memilih dan menyusun bahan ajar; (3) membantu memudahkan guru menentukan kegiatan belajar dan media pembelajaran; (4) memudahkan guru mengadakan penilaian.

Adapun mengenai perilaku peserta didik sebagai tujuan belajar, saat ini para ahli pada umumnya sepakat untuk menggunakan pemikiran dari Bloom sebagai tujuan pembelajaran. Bloom mengklasifikasikan ke dalam tiga ranah atau kawasan, yaitu: (1) kawasan kognitif yaitu kawasan yang berkaitan aspek-aspek intelektual atau berfikir/nalar, di dakamnya mencakup: pengetahuan (knowledge), pemahaman (comprehension), penerapan (application), penguraian (analysis), memadukan (synthesis), dan penilaian (evaluation); (2) kawasan afektif yaitu kawasan yang berkaitan aspek-aspek emosional, seperti perasaan, minat, sikap, kepatuhan terhadap moral dan sebagainya, di dalamnya mencakup: penerimaan (receiving/attending), sambutan (responding), penilaian (valuing), pengorganisasian (organization), dan karakterisasi (characterization); dan (3) kawasan psikomotor yaitu kawasan yang berkaitan dengan aspek-aspek keterampilan yang melibatkan fungsi sistem syaraf dan otot (neuronmuscular system) dan fungsi psikis. Kawasan ini terdiri dari: kesiapan (set), peniruan (imitation, membiasakan (habitual), menyesuaikan (adaptation) dan menciptakan (origination). Taksonomi ini merupakan kriteria yang dapat digunakan oleh guru untuk mengevaluasi mutu dan efektivitas pembelajarannya (Gulo, 2005).

Tujuan pembelajaran bahasa Arab sesuai Peraturan Menteri Agama No.2 Tahun 2008 adalah sebagai berikut: Mata pelajaran bahasa Arab merupakan suatu mata pelajaran yang diarahkan untuk mendorong, membimbing, mengembangkan, dan membina kemampuan serta menumbuhkan sikap positif terhadap bahasa Arab, baik reseptif maupun produktif. Kemampuan reseptif yaitu kemampuan untuk memahami pembicaraan orang lain dan memahami bacaan. Kemapuan produktif yaitu kemampuan menggunakan bahasa sebagai alat komunikasi baik secara lisan maupun secara tertulis. Kemampuan berbahasa Arab serta sikap positif terhadap bahasa Arab tersebut sangat penting dalam membantu memahami sumber ajaran Islam yaitu Al-Qur'an dan Al-Hadis, serta kitab-kitab berbahasa Arab yang berkenaan dengan Islam bagi peserta didik. Adapun visi PSPD FIK UIN yakni Menjadikan PSPD FIK UIN Syarif Hidayatullah sebagai lembaga pendidikan tinggi kedokteran yang berdaya saing tinggi, terkemuka dan terdepan dalam mengembangkan dan mengintegrasikan aspek keislaman, keilmuan kedokteran dan kesehatan, kemanusiaan, dan keindonesiaan. Sedangkan misinya adalah :

1. Menyiapkan peserta didik untuk menjadi dokter muslim yang memiliki etika dan moral berlandaskan nilai-nilai keislaman dalam menjalankan keprofesiannya dan memiliki keunggulan kompetitif dalam persaingan global 
2. Meningkatkan kualitas penyelenggaraan pendidikan untuk mengembangkan dan mengintegrasikan aspek keislaman, ilmu kedokteran serta keIndonesiaan.

3. Meningkatkan kualitas penelitian yang bermanfaat bagi pengembangan ilmu dan teknologi kedokteran dan kesehatan serta kemaslahatan masyarakat.

4. Meningkatkan kualitas hidup masyarakat melalui kegiatan pengabdian kepada masyarakat dalam bidang kedokteran dan kesehatan.

5. Memberikan kesempatan bagi lulusan madrasah/pesantren untuk mendapatkan pendidikan tinggi bidang kedokteran dan ilmu kesehatan yang bermutu.

6. Membangun kepercayaan dan mengembangkan kerjasama dengan lembaga nasional, regional maupun internasional.

\section{Kondisi awal mahasiswa PSPD FKIK UIN Jakarta angkatan 2012/2013}

Mahasiswa PSPD FIK UIN JAKARTA berasal dari latar belakang sekolah yang berbeda, yang mayoritas dari sekolah umum. Bahkan terdapat mahasiswa yang berasal dari Palestina. Karena itu, mereka memiliki latar belakang bahasa dan budaya yang berbeda dengan mahasiswa Indonesia pada umumnya. Selain itu, mereka juga memiliki latar belakang pengetahuan dan keterampilan berbahasa Arab yang bervariasi. Oleh karena itu, gaya dan strategi belajarnya pun harus bervariasi dan sesuai dengan kebutuhan mereka. Dalam pembelajaran seperti ini, maka dibutuhkan pemilihan materi bahasa Arab yang akan diajarkan. Hal ini sejalan dengan pendapat Ellis (1986) bahwa pemerolehan bahasa kedua dipengaruhi secara kuat oleh bahasa pertama. Lebih lanjut, Lee (1986) mengatakan bahwa satusatunya penyebab kesulitan dan kesalahan dalam belajar bahasa kedua atau bahasa asing adalah pengaruh bahasa pertama pelajar.

Pada tahap pendidikan umum di prodi PSPD, terdapat modul bahasa sebanyak 4 SKS selama dua semester, termasuk baha Arab yang dilaksanakan 2 SKS persemester. Namun setelah hampir tujuh tahun berjalan, modul bahasa terkesan berdiri sendiri dan tidak terintegrasi dengan modul-modul lainnya. Hal ini disebabkan karena pengelolaan modul tidak diserahkan kepada prodi dan Medical Education Unit (MEU), sehingga hasil keluaran modul menjadi tidak jelas yang berakibat pada timbulnya kesan bahwa modul bahasa hanya menjadi pelengkap saja. Mengacu kepada permasalahan yang ada, yaitu terkait pelaksanaan modul bahasa yang kurang terarah dan transparan, maka konsep pengembangan pada penelitian ini difokuskan pada proses pengembangan modul, penekanan strategi pembelajaran dan sasaran pembelajaran agar modul bahasa dapat bermanfaat bagi peningkatan profesionalisme dan pengembangan ilmu kedokteran itu sendiri. Strategi pembelajaran juga harus bersifat student centered dengan materi bahasan yang contextual atau berhubungan dengan dunia kedokteran.

Pengembangan dari kebutuhan tersebut maka dirancang suatu pembelajaran dengan menggunakan model assisted learning metode scaffolding. Hal ini sejalan dengan teori belajar konstruktivisme yang mendukung kurikulum dan pengajaran student centered. Scaffolding selalu digunakan untuk mendukung pembelajaran berbasis masalah ((Problem Based Learning) (Cahyo). Gambaran umum mengenai konsep pengembangan dapat dilihat pada gambar berikut: 


\section{Gambar 1. Konsep pengembangan inovasi}

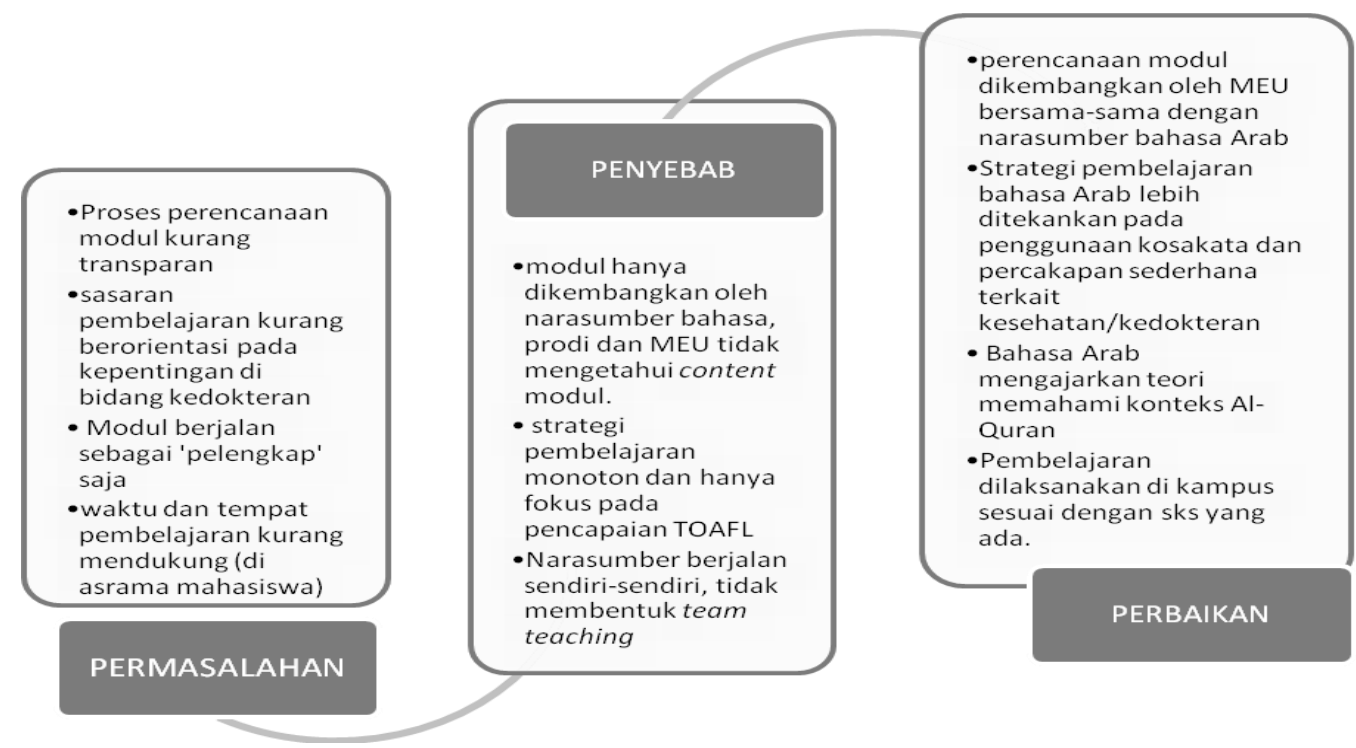

\section{Interpretasi Hasil Analisis Kebutuhan}

Temuan yang diperoleh dari analisis kebutuhan membuktikan bahwa terdapat permasalahan dalam pembelajaran mata kuliah Bahasa Arab untuk Program Studi Pendidikan Dokter (PSPD) FIK UIN Jakarta. Hal tersebut tercermin dalam jawaban yang diberikan oleh responden mahasiswa dan para pengajar bahasa Arab serta pimpinan prodi. Berikut pemaparan mengenai temuan - temuan yang penulis peroleh dari analisis data.

Secara umum dapat dikatakan bahwa kemampuan berbahasa Arab mahasiswa di PSPD diketahui sangat rendah. Ini ditemukan dalam analisis kesulitan penguasaan bahasa Arab mahasiswa yang menunjukkan kesulitan terhadap keterampilan berbicara berada pada urutan pertama, lalu diikuti keterampilan menyimak, menulis dan qawaid. Namun, dengan jumlah SKS yang terbatas dan kemampuan mahasiswa yang rendah, tidak memungkinkan bagi mahasiswa untuk mempelajari empat keterampilan sekaligus dalam satu semester. Untuk mengatasi hal ini, penulis memutuskan untuk menekankan keterampilan berbicara sebagai materi utama dalam rancangan silabus yang baru. Keterampilan berbicara yang akan dipelajari mahasiswa terbagi ke dalam dua rancangan, yaitu berbicara secara intensif yang dilakukan di dalam kelas dan keterampilan berbicara ekstensif akan dilakukan di luar kelas.

Berikut disajikan tabel analisis kebutuhan mahasiswa PSPD FIK UIN Jakarta dalam pembelajaran bahasa Arab:

Tabel 1. Analisis Kebutuhan Tujuan Belajar Bahasa Arab bagi Mahasiswa

\begin{tabular}{cc}
\hline VARIABEL & KEBUTUHAN \\
\hline I. Tujuan belajar Bahasa Arab & 1. Mahasiswa merasa penting belajar bahasa Arab. \\
& $\begin{array}{l}\text { 2. Tujuan yang ingin dicapai adalah untuk bisa memahami ayat } \\
\text { AlQuran dan Hadist., terutama yang berkaitan dengan bidang } \\
\text { kedokteran. }\end{array}$ \\
\hline
\end{tabular}




\section{II.Materi Bahasa Arab}

\section{III.Metode Pengajaran}

\section{IV.Evaluasi Pengajaran}

3. Mampu memahami makna sebagian surah pendek di dalam Juz Amma, juz ke-30 Al-Quran.

1. Keterampilan berbahasa yang utama dibutuhkan adalah berbicara (kalaam).

2. Kosakata-kosakata yang dibuthkan adalah kosakata dalam tema aktivitas sehari-hari dan kosakata bidang kedokteran.

1. Belajar bahasa arab untuk tujuan khusus, supaya membantu jika kelak ditugaskan ke Arab sebagai petugas medis Haji.

2. Bahasa Arab sebaiknya diajarkan menjelang semester akhir, agar setelah lulus, masih segar diingat (jika pada awal-awal semester, maka begitu lulus bahasa Arab sudah dilupakan).

3. Kesulitan yang dialami dalam belajar bahasa Arab adalah faktor Aswat Arabiyyah (bunyi kata bahasa Arab), dan metode pengajaran yang monoton dan membosankan. Maka diperlukan sebuah metode yang tepat.

4. Gaya belajar yang disenangi adalah visual dan kinestetik.

5. Sumber belajar yang dibutuhkan adalah kamus, internet dan nara sumber yang kompeten.

1. Bentuk evaluasi tes tulis, lisan, dan kuis.

2. Bobot nilai yang diharapkan; $40 \%$ Formatif, 30\% UTS dan 30\% UAS.

3. Tugas formatifyang disukai adalah tugas kelompok, alasannya adalah bisa belajar kepada yang lebih mahir.

4. Waktu yang tepat untuk belajar bahasa Arab adalah pagi hari.

5. Profil dosen yang diharapkan dalam belajar bahasa Arab adalah; komunikatif dan bersahabat (supaya tidak segan untuk bertanya), luwes dan tidak membosankan.

\section{Desain Kurikulum Pembelajaran Bahasa Arab di PSPD FIK UIN Jakarta}

Terkait dengan permasalahan yang telah diungkapkan diatas maka pengembangan pengajaran bahasa Arab ini akan meliputi beberapa hal, yaitu; perencanaan pengembangan modul, restrukturisasi materi pembelajaran, model atau strategi pembelajaran, sistem penilaian, dan keberlanjutan dalam modul. Secara terperinci implementasi pada kelima hal tersebut adalah sebagai berikut,

Tabel 2. Penjelasan konsep pengembangan dan mekanisme pelaksanaannya

\begin{tabular}{|c|c|c|c|}
\hline $\mathrm{NO}$ & $\begin{array}{r}\text { UNSUR PE } \\
\text { PENGEN }\end{array}$ & $\begin{array}{l}\text { RBAIKAN \& } \\
\text { BANGAN }\end{array}$ & MEKANISME PELAKSANAAN \\
\hline 1 & $\begin{array}{l}\text { Perencanaan } \\
\text { modul }\end{array}$ & pengembangan & $\begin{array}{l}\text { - MEU, Prodi bersama dengan narasumber bahasa Arab } \\
\text { merumuskan bersama materi, metode dan sasaran pembelajaran. } \\
\text { Termasuk didalamnya jumlah jam pertemuan yang disepakati di } \\
\text { dalam modul } \\
\text { - Pertemuan selambat-lambatnya diselenggarakan satu bulan } \\
\text { sebelum modul berjalan }\end{array}$ \\
\hline 2 & $\begin{array}{l}\text { Restrukturisasi } \\
\text { pembelajaran }\end{array}$ & materi & $\begin{array}{l}\text { - Fokus pada penerjemahan ayat/hadis yang berhubungan dengan } \\
\text { kedokteran dan beberapa surat pilihan } \\
\text { - Penentuan kosakata-kosakata bidang kedokteran serta materi }\end{array}$ \\
\hline
\end{tabular}




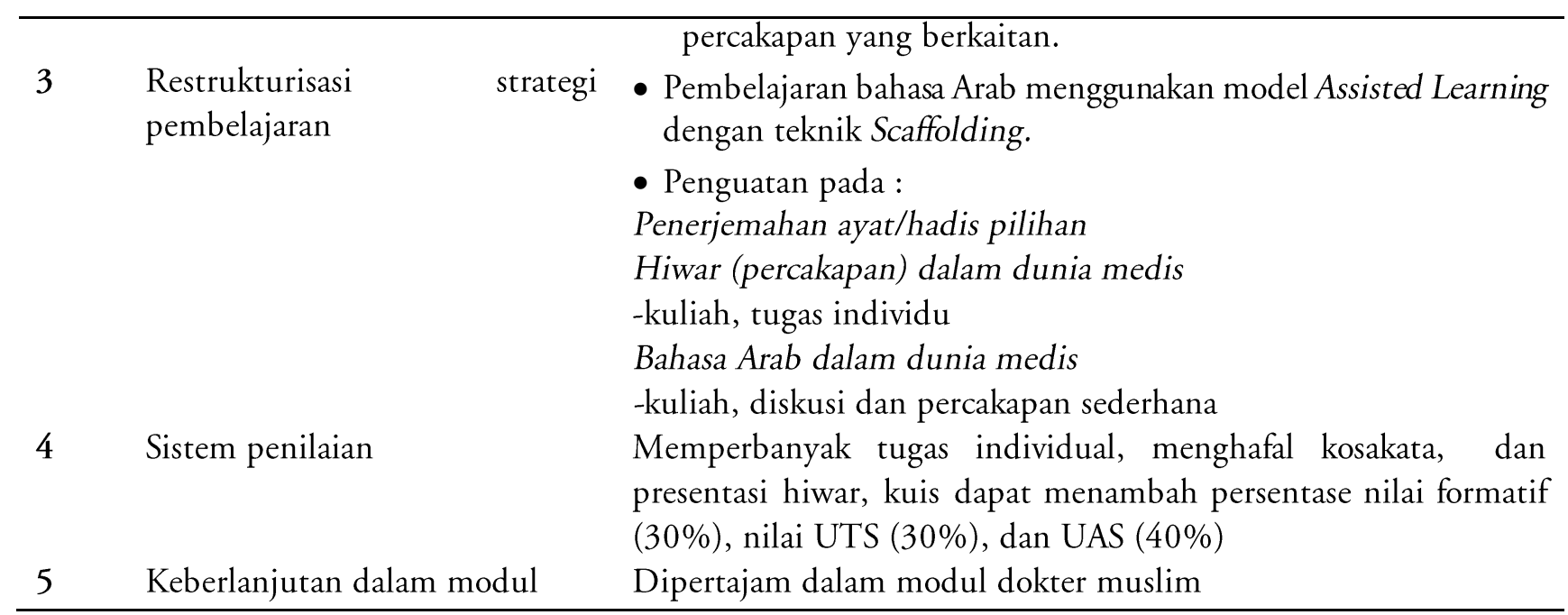

Kegiatan modul bahasa dimulai dari tahap penyusunan modul oleh tim narasumber bahasa Arab, tim PJ modul dan perwakilan Medical Education Unit (MEU). Pertemuan tersebut dilaksanakan dengan fokus pada content modul yang bermanfaat bagi pengembangan profesionalisme kedokteran. Pada pelaksanaannya modul bahasa dibagi menjadi dua kelompok besar yaitu 50 orang sebagai kelompok A, 50 orang berikutnya adalah kelompok B. Pembagian kelompok untuk memudahkan proses pembelajaran agar bahasa Arab dapat berjalan di satu waktu. Waktu untuk modul bahasa adalah setiap Jumat jam 13.00-16.00, yang dibagi masing-masing modul 90 menit, dengan narasumber bahasa Arab sebanyak dua orang.

Secara umum, pelaksanaan modul telah berjalan sesuai rencana, tolok ukur keberhasilan juga telah tercapai $90 \%$, dengan rata-rata peningkatan nilai pre test-post test bahasa Arab $56.22 \%$. Pada tabel dibawah ini dapat dilihat indikator keberhasilan pelaksanaan modul pengajaran.

Tabel 3. Indikator pengkuran modul bahasa Arab

\begin{tabular}{|c|c|c|}
\hline INDIKATOR PENGUKURAN & AKHIR MODUL & REALISASI \\
\hline $\begin{array}{l}\text { Perencanaan modul yang } \\
\text { transparan }\end{array}$ & Buku modul terdokumentasi & ya \\
\hline $\begin{array}{l}\text { Materi pembelajaran bahasa } \\
\text { Arab bermanfaat untuk } \\
\text { percakapan sederhana di bidang } \\
\text { kedokteran }\end{array}$ & 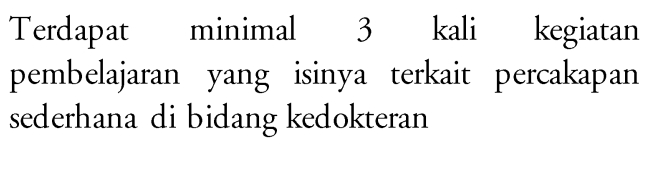 & $\begin{array}{l}2 \text { kali terlaksana karena terpotong } \\
\text { libur, terdokumentasi video } \\
\text { percakapan berbahasa Arab }\end{array}$ \\
\hline $\begin{array}{l}\text { Materi pembelajaran bahasa } \\
\text { Arab bermanfaat untuk } \\
\text { memahami teks Al-Quran }\end{array}$ & $\begin{array}{l}\text { Terdapat minimal } 3 \mathrm{kali} \text { kegiatan } \\
\text { pembelajaran yang isinya memahami teks Al- } \\
\text { Quran }\end{array}$ & $\begin{array}{l}2 \text { kali terlaksana karena terpotong } \\
\text { libur }\end{array}$ \\
\hline
\end{tabular}

Pada akhir modul bahasa diedarkan kuesioner untuk mengevaluasi proses pelaksanaan modul bahasa. Hasil analisis kuesioner adalah sebagai berikut; 43\% bermanfaat mendukung profesionalisme dokter, 61\% bahasa Arab mendukung Dokmus, 63\% membantu memahami ayat dokmus, dan 45\% strategi belajar memudahkan belajar bahasa Arab. 


\section{Implementasi Metode Assisted Learning Model Scaffolding dalam Pembelajaran bahasa Arab}

Strategi atau metode yang digunakan dalam pembelajaran modul bahasa arab di PSPD FIK UIN Jakarta adalah model Scaffolding. Adapun secara sistematis langkah-langkah yang ditempuh adalah sebagai berikut:

1. Menjelaskan materi pembelajaran.

Pada langkah ini, di awal pertemuan dosen menjelaskan mengenai isi modul yang telah dibagikan kepada mahasiswa, bagaimana teknik belajarnya, sistem penilaian dan sebagainya yang biasanya disebut dengan istilah kontrak belajar, sebelum pembelajaran dilanjutkan.

2. Menentukan zone of proximal development (ZPD) atau level perkembangan mahasiswa berdasarkan tingkat kognitifnya dengan melihat nilai hasil belajar sebelumnya.

Dalam langkah ini, pada pertemuan pertama dosen mengadakan pre test yang bertujuan untuk mengetahui sejauh mana tingkat penguasaan awal mahasiswa. Hasil pre test ini akan dijadikan sebagai acuan untuk menentukan apakah materi yang diberikan pada pre test tersebut terlalu mudah ataukah terlalu sulit menurut tingkat penguasaan mahasiswa. Jika hasilnya terlalu mudah maka dosen akan merestrukturisasi kembali isi materi yang akan diajarka selanjutnya. Demikian halnya juga jika materi terlalu sulit.

3. Mengelompokkan siswa berdasarkan ZPD-nya.

Selain itu juga hasil pre test akan dijadikan untuk menentukan pembagian kelompok mahasiswa supaya dapat terbentuk kelompok yang merata. Fungsi lainnya adalah untuk menentukan mahasiswa yang mempunyai nilai (ZPD) tinggi untuk diberikan tugas khusus, yakni menjadi pembimbing bagi mahasiswa yang memiliki nilai (ZPD) rendah.

4. Memberikan tugas belajar berupa soal-soal berjenjang yang berkaitan dengan materi pembelajaran.

Pada langkah ini, dosen memberikan tugas mingguan secara bergilir kepada tiap-tiap kelompok untuk mendiskusikan materi yang terdapad pada modul.

5. Mendorong mahasiswa untuk bekerja dan belajar menyelesaikan soal-soal secara mandiri dengan berkelompok.

Disamping tugas kelompok untuk diskusi mingguan, mahasiswa juga diberikan tugas mandiri, misalnya menghafal mufrodat (kosakata) minimal 10 buah.

6. Memberikan bantuan berupa bimbingan, motivasi, pemberian contoh, kata kunci atau hal lain yang dapat memancing mahasiswa ke arah kemandirian belajar.

Jika ada mahasiswa yang belum bisa menyelesaikan tugasnya meskipun dalam kelompok, maka mahasiswa diberikan kesempatan berkonsultasi dengan dosen. Dalam proses pembelajaran, dosen juga menggunakan metode kuis baik berupa pertanyaan langsung maupun berupa kesempatan untuk mendapatkan nilai tambahan bagi mahasiswa yang bersedia tampil ke depan kelas untuk mempraktekkan hiwar (berdialog dalam bahasa Arab).

7. Mengarahkan siswa yang memiliki ZPD yang tinggi untuk membantu siswa yang memiliki ZPD rendah. 
Langkah ini diawali dengan melihat hasil pre test mahasiswa, selanjutnya dosen menunjuk mahasiswa yang memiliki nilai tinggi untuk menjadi ketua kelompok, yang bertugas membimbing teman-temannya supaya berhasil dalam belajarnya.

8. Menyimpulkan pelajaran dan memberikan tugas-tugas.

Pada akhir modul, dosen mengadakan review untuk semua materi yang terdapat dala modul. Jika ada bagian materi yang masih belum dimengerti, maka akan didiskusikan kembali. Adapun tugas yang diberikan mahasiswa yaitu mengidentifikasi dan mengorganisir semua mufrodat (kosakata) yang telah dipelajari, menjadi semacam kamus mini. Tugas ini bermanfaat untuk memudahkan mahasiswa menghafal kembali kosakata yang diperlukan.

Tugas lainnya adalah membuat dialog pendek dalam bahasa Arab tentang tema-tema yang telah dipilihkan dosen untuk mahasiswa.

Di dalam perencanaan pembelajaran, dosen menyiapkan materi bahan ajar yang tepat dan relevan berdasarkan kebutuhan. Diantaranya yaitu materi tentang المستشفىى (rumah sakit), الأمراض (penyakit) dan lainnya, termasuk ayat-ayat Al-Qur'an yang berkaitan dengan bidang kedokteran. Misalnya Q.S. Al Mu'minuun ayat 14 (proses perkembangan embrio), Q.S. Al A'raaf ayat 31 (tentang anjuran menjaga kesehatan dan kebersihan pakaian dan makanan). Selain itu juga ayat yang berkaitan dengan modul Islamic Studies, misalnya emphaty diantaranya terdapat dalam Q.S. Al Hujuraat ayat 10. Demikian juga dengan hadist-nya, contohnya Hadis Riwayat Bukhari No.13:

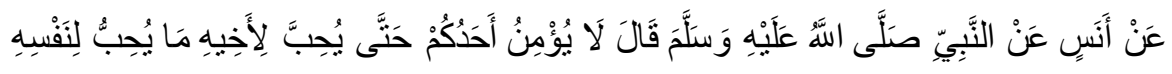

Implementasi teknik scaffolding dalam pembelajaran bahasa, termasuk bahasa Arab, dilandasi oleh pemikiran bahwa aspek-aspek bahasa selalu digunakan secara terpadu, baik aspek berbicara (Kalaam), membaca (Qira'ah), menyimak (Istima') maupun menulis (Kitaabah).

\section{a. Aspek berbicara (kalaam)}

Dalam pelaksanaanya, ada beberapa contoh yang dilaksakan, yaitu;

1. Dosen menceritakan sebuah peristiwa dan siswa menyimaknya dengan baik. Setelah selesai, mahasiswa diberi waktu sejenak untuk mengartikan dan memahami apa yang dimaksud dalam cerita tersebut. Kemudian dosen menunjuk beberapa mahasiswa untuk menceritakan kembali isi cerita tersebut dengan kalimat-kalimat mahasiswa sendiri secara ringkas.

2. Dosen telah mempersiapkan beberapa orang mahasiswa untuk mengadakan dialog secara berpasangan dengan rambu-rambu yang telah ditetapkan oleh dosen. Pada waktu yang telah ditentukan, mahasiswa yang mendapat tugas melakukan dialog di depan kelas, mahasiswa yang lain menyimak. Hal ini dilakukan secara bergilir dengan menggunakan kosakata yang berbeda-beda.

\section{b. Aspek membaca (qira'ah)}

Dalam pelaksanaanya, ada beberapa contoh yang dilaksakan, yaitu;

Mahasiswa diberikan tugas membaca suatu wacana (bacaan) pendek yang telah disediakan oleh dosen. Dalam hal ini, ketentuan-ketentuan membaca untuk mahasiswa yang lain harus dipahami, sehingga wajib menyimak. Setelah selai, mahasiswa diberikan waktu untuk berpikir 
dan memahami isi dari wacana yang telah dibaca. Tugas selanjutnya, mahasiswa diminta untuk menceritakan kembali isi yang disimak secara tertulis ataupun lisan.

\section{c. Aspek menyimak (istima) dan menulis}

Dosen membacakan sebuah ayat pendek dari Al Qur'an atau hadist, dan mahasiswa menyimak sambil menulis apa yang dibacakan oleh dosen. Setelah selesai, semua hasil pekerjaan mahasiswa dikumpulkan. Beberapa mahasiswa diminta membacakan hasil tulisan temannya di depan kelas. Setelah selesai kemudian dibagikan lagi secara acak untuk mencocokkan kembali apa yang dibacakan dosen dengan apa yang disimak dan ditulis oleh mahasiswa. Dengan cara seperti itu, telah terjadi pemaduan antara menyimak, menulis, dan membaca.

\section{d. Aspek tata menulis (kitaabah)}

Pembelajaran tata bahasa (qawaid) dipadukan dengan semua aspek keterampilan. Diawali dengan pemberian kosakata-kosakata yang telah disiapkan, dibacakan, didiskusikan maknanya, sinonimnya (jika ada), dan sebagainya. Kemudian mahasiswa diminta untuk menggunakan kata-kata tersebut dalam kalimat secara tertulis . dosen juga terkadang menggunakan kaatakata itu dalam wacana untuk dikte. Dengan cara seperti ini, dapat dilakukan pemaduan antara membaca, menulis, berbicara, dan menyimak.

Dari sekian banyak teori tentang strategi pembelajaran, baik yang konvensional maupun kontemporer sesungguhhnya tidak akan memberikan manfaat besar jika pendidik sebagau ruh dalam pembelajaran bahasa tidak dapat menggunakan kreatifitasnya dalam mengaplikasikan berbagai strategi tersebut. Dosen yang secara akademis berkualifikasi tinggi dalam bidang bahasa Arab, belum tentu ia akan pandai pula dalam mengajar. Karena seperti banyak dikatakan bahwa "teaching is art", dan di dalam art itu membutuhkan kreatifitas. Selain itu, seorang pendidik juga harus mempunyai rasa empati terhadap peserta didiknya.

Adapun hambatan yang dirasakan selama modul berjalan adalah ketersediaan kelas untuk pembelajaran, yang semula direncanakan di lantai 5 (519 dan 520) untuk bahasa Arab, pada realisasinya, kelas sering berpindah dikarenakan terkadang lantai 5 digunakan untuk ujian OSCE, ujian skripsi mahasiswa farmasi, sehingga bahasa Arab pun dipindahkan di lantai 1. Sebenarnya jauhnya lokal kelas yang digunakan berpengaruh pada lamanya waktu yang digunakan, sehingga banyak waktu mahasiswa tersita untuk belajar. Oleh karena itu di masa mendatang diharapkan pihak fakultas dapat meyediakan ruang kelas yang lebih representatif lagi.

\section{Penutup}

Berdasarkan hasil deskripsi dan analisa data, maka dapat disimpulkan bahwa Kebutuhan mahasiswa PSPD FKIK UIN Jakarta dalam pembelajaran bahasa Arab, selain untuk tujuan umum yakni dapat memahami AlQur'an dan Hadist yang keduanya merupakan sumber pokok ajaran dan hukum Islam, juga untuk tujuan yang lebih khusus lagi yakni agar dapat berkomunikasi dalam bahasa Arab saat pergi haji maupun saat bertugas sebagai tim medis petugas haji. Selain itu, tujuan pembelajaran bahasa Arab bertujuan sebagai pendukung kompetensi modul lain yang dipelajari di PSPD, yakni supaya terintegrasi dengan modul Dokter Muslim. Sehinngga Kegiatan modul bahasa Arab dengan menggunakan metode pembelajaran Assisted learning model scaffolding telah berjalan cukup efektif, $90 \%$ sesuai dengan rencana. Pada modul bahasa Arab didapatkan peningkatan nilai pretest terhadap posttest sebesar 
56.22\%. Menurut mahasiswa, materi pembelajaran bahasa Arab dapat berkonstribusi dalam peningkatan profesionalisme dokter.

\section{Daftar Pustaka}

Agus N. Cahyo.2013. Panduan Aplikasi Teori-Teori Belajar Mengajar Teraktual dan Terpopuler. Cet.I. Jogjakarta: Diva Press.

Azhar Arsyad, 2010. Bahasa Arab dan Metode Pengajarannya, Yogyakarta: Pustaka Pelajar, Cet. Ke-3

Ellis, Rod. 1986. Understanding Second Language Acquisition. Oxford: Oxford University Press

Hendri Guntur Taringan, Dasar-dasar Kurikulum Bahasa.

Nana Sudjana, 2009, Dasar-Dasar Proses Belajar Mengajar, (Bandung : Sinar Baru Al Gensindo.

Nana Syaodih Sukmadinata, 2002, Pengembangan Kurikulum: Teori dan Praktek, Bandung: PT Remaja Rosdakarya.

Nation, J dan Macalister I.S.P. 2010. Language Curriculum Design. New York:Routledge.

Oemar Hamalik, 2008, Dasar-dasar Pengembangan Kurikulum, (Bandung : PT Remaja Rosdakarya.

Soenjono Dardjowidjojo. 2000. "Pengajaran, Pembelajaran, dan Pemerolehan Bahasa Asing" dalam Kajian Serba Linguistik: Untuk Anton Moeliono Pereka Bahasa. Jakarta: PT. BPK Gunung Mulia.

Team Dedaktik Metodik Kurikulum, 1993, Penganatar Dedaktik Metodik Kurikulum, PBM, Jakarta : PT. Raja Grafindo Persada.

W. Gulo, 2005, Strategi Belajar Mengajar, Jakarta : Grasindo.

Zakiah Daradjat, dkk, 1996. Metodologi Pengajaran Agama Islam, Jakarta: Bumi Aksara. 